\title{
Sonnivasikat oppivat varomaan sähköpaimenaitaa nopeasti
}

\author{
Paula Martiskainen $^{1)}$, Leena Tuomisto ${ }^{2)}$, Arto Huuskonen ${ }^{3)}$ ja Jaakko Mononen ${ }^{1)}$ \\ ${ }^{1)}$ Kuopion yliopisto, Soveltavan biotekniikan instituutti, PL 1627, 70211 Kuopio, etu- \\ nimi.sukunimi@uku.fi \\ ${ }^{2)}$ MTT, Kotieläintuotannon tutkimus, Kuopion yliopisto, Biotieteiden laitos, PL 1627, 70211 Kuopio, \\ leena.tuomisto@mtt.fi \\ ${ }^{3)}$ MTT, Kotieläintuotannon tutkimus, Halolantie 31 A, 71750 Maaninka, arto.huuskonen@mtt.fi
}

\section{Tiivistelmä}

Laitumelta karkailevat hiehot ovat tuttu alkukesän ilmiö useilla suomalaisilla maatiloilla. Maitorotuisia sonnivasikoita tai sonneja ei taas ole Suomessa yleensä laidunnettu lainkaan. Maitotiloilla laitumien aitaamiseen käytetään pääasiallisesti kustannuksiltaan edullisia kevyitä sähköpaimenaitoja, jotka eivät kuitenkaan pysäytä eläimiä, elleivät ne ole oppineet kunnioittamaan aitoja laidunalueen rajoina. Tutkimuksemme tarkoituksena oli selvittää, kuinka nopeasti maitorotuiset sonnivasikat oppivat kunnioittamaan sähköpaimenaitaa ja kuinka niiden laiduntaminen onnistuu yksinkertaista aitausjärjestelyä käyttäen.

Tutkimuksessa käytettiin 19 ayrshire ja holstein-friisiläistä sonnivasikkaa. Vasikoita pidettiin kylmäpihatossa $8 \times 8 \mathrm{~m}$ karsinassa, jonka viereen pihaton päätyyn oli rakennettu betonielementeistä ja laudoista $4 \times 8 \mathrm{~m}$ jaloittelutarha. Noin $0,7 \mathrm{~m}$ lauta-aidan sisäpuolelle oli rakennettu sähköpaimenaita. Vasikoilla oli vapaa pääsy jaloittelutarhaan sähköpaimenaitaan opetuksen ajan, eli seitsemän vuorokautta ennen laidunkauden alkua. Eläinyksilöiden saamat sähköiskut laskettiin videonauhalta vasikoiden käyttäytymisen perusteella. Opetusjakson jälkeen vasikat päästettiin sähköpaimenaidoin aidatulle laitumelle neljän kuukauden ajaksi. Vasikoiden saamien sähköiskujen lukumäärää rekisteröitiin suorilla havainnoilla laitumelle laskun yhteydessä. Vasikoiden saamien sähköiskujen määrän muuttuminen opetusjakson ensimmäisten kahdeksan tunnin sekä neljän vuorokauden aikana testattiin lineaarisella sekamallilla.

Kaikki eläimet kävivät tutkimassa sähköpaimenlankaa ensimmäisen opetusvuorokauden aikana saaden siitä useita (vaihteluväli 8-37) sähköiskuja. Seuraavien vuorokausien aikana saatujen sähköiskujen määrä väheni $(P<0,001)$. Sähköiskujen määrän väheneminen oli tilastollisesti merkitsevä ensimmäisen $(17,3$ [13,9; 21,0], takaisinmuunnettu ryhmäkeskiarvo [95\% luottamusväli], sähköiskua) ja toisen $(6,0[3,8 ; 8,7])$ sekä kolmannen $(4,2[2,2 ; 6,7])$ ja neljännen $(0,2[0,0 ; 0,5])$ vuorokauden välillä. Vasikat saivat opetusjakson ensimmäisen tunnin aikana enemmän sähköiskuja $(\mathrm{P}<0,001)$ kuin sitä seuraavina seitsemänä tuntina. Laitumelle laskun yhteydessä havaittiin aitojen hyvän näkyvyyden olevan tärkeää. Vasikat eivät karanneet laitumelta laidunkauden aikana.

Vasikoiden saamien sähköiskujen lukumäärän perusteella vasikat oppivat selvästi varomaan jaloittelutarhassa ollutta sähköpaimenaitaa jo yhden vuorokauden aikana. Oppimista näyttää tapahtuneen jopa opetusjakson ensimmäisen tunnin aikana. Laidunkauden päättyessä sonnit olivat jo kahdeksan kuukauden ikäisiä, mutta niiden laiduntaminen kevytrakenteisessa sähköpaimenaitauksessa ei aiheuttanut lainkaan käytännön ongelmia. Sukupuolesta ja iästä riippumatta laiduneläinten riittävä opettaminen sähköpaimenaitoihin on suositeltavaa, sillä se parantaa sekä eläinten että niiden hoitajien turvallisuutta.

Asiasanat: vasikat, sonnit, oppiminen, laiduntaminen, aitausjärjestelyt 


\section{Johdanto}

Suomessa lypsykarjatiloilla laitumien aitaamiseen käytetään yleensä kevyitä sähköpaimenaitoja, joiden kustannukset jäävät huomattavasti kiinteitä aitoja matalammiksi (Seppänen 1978). Sähköpaimenen etuna on myös sen suhteellisen vaivaton siirrettävyys paikasta toiseen tarpeen mukaan. Sähköpaimenaidat eivät kuitenkaan pysäytä eläimiä, elleivät ne ole oppineet kunnioittamaan aitoja laidunalueen rajoina. Laitumelta karkailevat hiehot ovatkin tuttu alkukesän ilmiö useilla suomalaisilla maatiloilla. Maitorotuisia sonnivasikoita tai sonneja, joihin suomalainen naudanlihantuotanto pääosin perustuu (MMM 2002), ei taas ole yleensä laidunnettu lainkaan. Karjatilallisten mielipiteet ja kokemukset sonnivasikoiden ja sonnien laiduntamisesta ovat ristiriitaisia. Toisten mielestä sonnien laiduntaminen on suorastaan mahdotonta, ja toisilta se onnistuu käytännönkin tasolla ongelmitta. Syitä vähäiseen kiinnostukseen maitorotuisten sonnien laiduntamista kohtaan ovat mm. sonnien arvaamaton luonne, aitauskustannukset sekä eläinten heikentynyt kasvu laitumella (Hakkola ym. 1998). Sonnien laiduntamista on tutkittu Suomessa 1970-luvulla, jolloin todettiin yli $200 \mathrm{~kg}$ painoisten sonnien kuluttavan laitumella runsaasti aikaa ja energiaa eläinten keskinäisiin tappeluihin ja aitojen särkemiseen (Nisula \& Hakkola 1979).

Laitumelle pääseminen suo naudoille mahdollisuuden toteuttaa lajityypillistä käyttäytymistään, johon laiduntaminen olennaisesti kuuluu, sekä edistää eläinten hyvinvointia ja terveyttä (esim. Haskell ym. 2006, Hernandez-Mendo ym. 2007). Lisäksi Suomen olosuhteissa halvimmat rehuyksiköt saadaan laitumelta (Khalili \& Sairanen 2000), ja laidunnus voi vähentää eläinten hoitoon ja karsinoiden puhtaanapitoon kuluvaa työtä.

Naudat ovat uteliaita eläimiä ja ne tutkivat niille uusia asioita halukkaasti, joten "yrityksen ja erehdyksen" kautta oppiminen on naudoille ominainen oppimistapa (Phillips 1993), jota voidaan hyödyntää opetettaessa eläimiä varomaan sähköpaimenta. Niin kutsutussa assosiatiivisessa oppimisessa (katso esim. Barnard 2004) eläin oppii yhdistämään aitalangasta saamansa epämiellyttävän sähköiskun aitarakennelmaan, jolloin se välttää koskemasta aitaan myös kohdatessaan sen myöhemmin uudelleen. Assosiatiivisen oppimisen nopeus vaihtelee, eikä olekaan selvää, kuinka pitkän opettelujakson naudat tarvitsevat oppiakseen varomaan sähköpaimenaitaa riittävän varmasti. Käytännön kokemusten perusteella jopa yksi ainoa sähköisku aitalangasta voisi riittää eläinten opettamiseen.

Kokeemme tarkoituksena oli selvittää, kuinka nopeasti maitorotuiset sonnivasikat oppivat varomaan sähköpaimenaitaa ja kuinka niiden laiduntaminen onnistuu käytännössä yksinkertaista aitausjärjestelyä käyttäen. Laidunnuksen onnistumista testattiin myös eläinten yksivuotiskesänä. Kokemusten perusteella tehtiin suosituksia nautojen sähköpaimeneen opettamista ja laiduntamista varten.

\section{Aineisto ja menetelmät}

Koe suoritettiin Maa- ja elintarviketalouden tutkimuskeskuksen Ruukin toimipisteessä vuosina 20032004. Kokeessa käytettiin 19 ayrshire- ja holstein-friisiläistä sonnivasikkaa, jotka oli hankittu tutkimusasemalle vasikkavälityksestä noin kahden viikon iässä keväällä 2003. Vasikat kasvatettiin lämpimässä navetassa keskimäärin 70 päivän ikään, jolloin eläimet siirrettiin eristämättömään pihattoon. Vasikoita pidettiin pihatossa $8 \times 8 \mathrm{~m}$ karsinassa, josta puolet oli kuivitettua makuualuetta ja puolet betonista lantakäytävää. Karsinan viereen pihaton päätyyn rakennettiin betonielementeistä ja laudoista $4 \times 8 \mathrm{~m}$ jaloittelutarha (kuva 1A), jonka pohjalla oli paksu kerros haketta. Noin 0,7 m lauta-aidan sisäpuolelle rakennettiin harjoittelusähköpaimenaita, jossa oli neljä rautalankaa. Kaksi toisistaan noin 5 cm etäisyydellä olevaa lankaa sijaitsi noin $45 \mathrm{~cm}$ ja kaksi lankaa $70 \mathrm{~cm}$ korkeudella maasta. Sekä alaettä ylälangat oli yhdistetty toisiinsa muovieristimellä (kuva 1B). Aita virroitettiin verkkovirralla toimivalla paimenella (Olli 450, Farmcomp Oy, Tuusula), jonka suurin antojännite oli 5,6 kV.

Seitsemän vuorokautta ennen laidunkauden alkua (2.6.2003) aloitettiin vasikoiden sähköpaimenaitaan opettaminen, jolloin vasikat päästettiin ensimmäisen kerran jaloittelutarhaan noin klo 15 . Vasikoilla oli jatkuvasti vapaa pääsy jaloittelutarhaan ja sieltä takaisin karsinaan koko opetusjakson ajan. Sähköpaimenaitaan opettamisen aikana jaloittelutarhaa kuvattiin jatkuvasti mustavalkovideokameroilla aikaviivenauhoitusta (3 kuvaa/s) käyttäen. Videonauhoilta laskettiin eläinyksilöiden harjoitteluaidasta saamat sähköiskut jokaiselle jaloittelutarhaan päästämistä seuraavalle tunnin jaksolle koko seitsemän vuorokautta kestäneen harjoittelujakson ajan (yhteensä 168 h). Eläimen katsottiin saaneen sähköiskun, kun se joko perääntyi tai poistui nopeasti aidalta, irvisti tai rypisti turpaansa, ravisteli päätänsä, luimisti korvansa tai tuijotti aitaa kosketettuaan aitalankoja (sekä mikä tahansa yhdistelmä edellisistä). Vain varmasti sähköiskun saamiseksi tulkitut tapaukset rekisteröitiin. 
A)

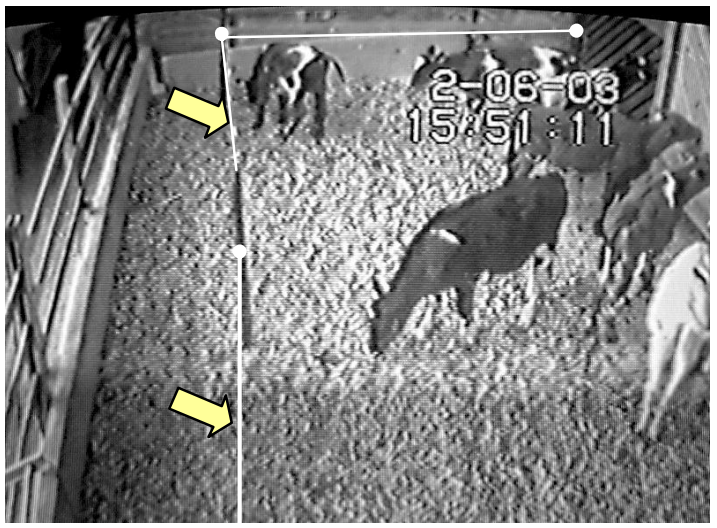

B)

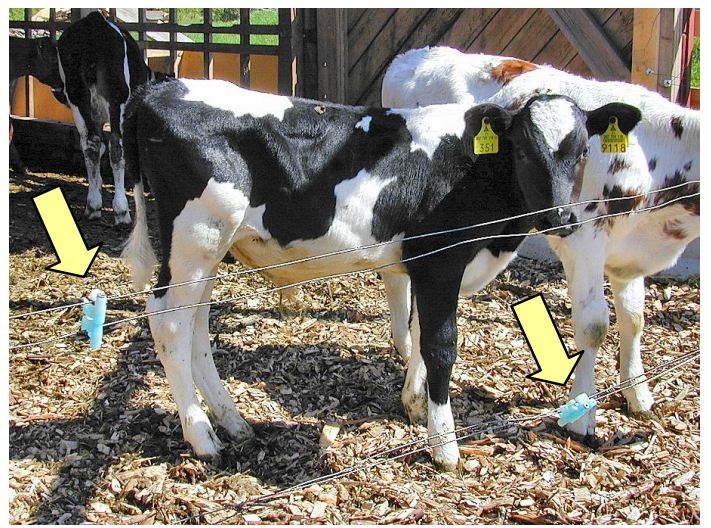

Kuva 1. A) Vasikoiden sähköpaimenaitaan opettamisessa käytetty jaloittelutarha. Harjoittelusähköpaimenaita (nuolet) sijaitsi tukevamman lauta-aidan sisäpuolella. B) Harjoitteluaidassa oli kaksi ylä- ja kaksi alalankaa, jotka oli yhdistetty muovisilla eristimillä (nuolet).

Opetusjakson jälkeen vasikat siirrettiin lohkolaidunnukseen neljän kuukauden ajaksi kahdessa 9-10 eläimen ryhmässä. Laitumien aidoissa oli kevyet lasikuitutolpat (paino $163 \mathrm{~g}$ ) ja kaksi rautalankaa arviolta samoilla korkeuksilla kuin harjoitteluaidassakin. Myös käytetty sähköpaimen oli sama kuin harjoitteluaidassa. Vasikoiden käyttäytymisestä laitumelle siirrossa kerättiin kuvailevaa tietoa suorilla havainnoilla laitumelle laskun aikana ja noin tunnin ajan laitumelle laskun jälkeen. Laidunkauden jälkeen eläimet siirrettiin talveksi eristämättömään pihattoon 4-5 eläimen ryhmissä. Yhdeksää vasikkana laitumella ollutta sonnia laidunnettiin vielä kesällä 2004 vastaavanlaisissa aidoissa kuin vasikoita kesällä 2003. Ennen varsinaista laitumelle laskemista sonneja pidettiin vuorokauden ajan siirrettävistä metallisista aitaelementeistä laitumelle rakennetussa noin $8 \times 8 \mathrm{~m}$ aitauksessa, jonka sisälle oli rakennettu vasikoiden harjoitteluaitaa vastaava sähköpaimenaita. Sonnien käyttäytymistä seurattiin suorilla havainnoilla tunnin ajan aitaukseen siirron jälkeen sekä laitumelle laskun yhteydessä. Eläinten pysymistä laidunaidoissa seurattiin molempien laidunkausien ajan. Eläinten kasvu ja muut tuotantoparametrit on raportoitu julkaisussa Jansson ym. (2007).

Vasikoiden saamien sähköiskujen määrän muuttuminen opetusjakson ensimmäisten kahdeksan tunnin sekä neljän vuorokauden aikana testattiin lineaarisella sekamallilla (SPSS for Windows 14.0). Kolmen viimeisen vuorokauden aineisto poistettiin tulosten käsittelystä sähkökatkosta ja eläinten punnituksista aiheutuneiden häiriöiden takia. Tulosmuuttujalle tehtiin Box-Cox -muunnos (Box \& Cox 1964) aineiston normalisoimiseksi. Analyysissä käytetty tilastollinen malli oli muotoa:

$Y_{i j}=\mu+\beta_{i}+\varepsilon_{i j}$

jossa $Y_{i j}=$ sähköiskujen lukumäärä, $\mu=$ yleiskeskiarvo, $\beta_{i}=$ opetusjakson tunnin tai vuorokauden kiinteä vaikutus ja $\varepsilon_{i j}=$ eläinyksilön virhetermi. Akaiken informaatiokriteerin perusteella valittiin virhetermien kovarianssirakenteeksi ARH opetusjakson tunnin vaikutuksen analyysissä ja ARH(1) opetusjakson vuorokauden vaikutuksen analyysissä. Opetusjakson tuntien tai päivien väliset pareittaisvertailut tehtiin käyttäen Bonferroni-korjausta. Tulokset on esitetty käänteismuunnoksen avulla takaisinmuunnetuista korjatuista ryhmäkeskiarvoista. Takaisinmuunnoksen takia hajonnan tunnuslukuna käytetään $95 \%$ luottamusväliä.

\section{Tulokset ja tulosten tarkastelu}

\section{Vasikat}

Kaikki eläimet kävivät opetusjakson ensimmäisen vuorokauden aikana tutkimassa harjoitteluaitaa saaden siitä useita (vaihteluväli 8-37) sähköiskuja. Useimmat vasikat kävivät tutkimassa harjoitteluaitaa ja saivat siitä ensimmäisen sähköiskunsa opetusjakson ensimmäisen tunnin aikana, yksi vasikka opetusjakson toisen ja kolme vasikkaa opetusjakson kolmannen tunnin aikana. Tämä voi olla seurausta eläinten yksilöllisistä luonne-eroista, jolloin aremmilta eläimiltä on kulunut pidempi aika uskaltautua tutkimaan elinympäristöönsä ilmestynyttä uutta asiaa. 
Vasikoiden saamien sähköiskujen lukumäärä tunnissa väheni nopeasti harjoittelujakson alussa, minkä jälkeen sähköiskujen maksimilukumäärä tunnissa pysyi melko tasaisena harjoittelujakson loppuun saakka (kuva 2). Vasikat saivat harjoitteluaidasta enemmän sähköiskuja $\left(\mathrm{F}_{7,73}=4,4 ; \mathrm{P}<0,001\right.$, lineaarinen sekamalli) harjoittelujakson ensimmäisen tunnin kuin sitä seuraavien seitsemän tunnin aikana, vaikkakaan ero ei ollut tilastollisesti merkitsevä tuntien 1 ja 4 välillä (kuva 3). Vasikoiden saamien sähköiskujen lukumäärä väheni $\left(\mathrm{F}_{3,37}=76,8\right.$; $\left.\mathrm{P}<0,001\right)$ myös harjoittelujakson päivästä 1 päivään 2 ja päivästä 3 päivään 4 mentäessä (kuva 4). Vain yksi 19 vasikasta ei saanut harjoitteluaidasta yhtään sähköiskua ensimmäisen harjoittelupäivän jälkeen. Opetusjaksolla vasikoiden käytössä ollut jaloitteluaitaus ei sinällään tarjonnut vasikoille ylimääräisiä virikkeitä lisätilaa ja harjoitteluaitaa lukuun ottamatta. Vasikat ovatkin voineet sähköiskuista huolimatta jatkaa harjoitteluaidan tutkimista toteuttaakseen lajityypillistä leikki- ja tutkimiskäyttäytymistä (katso esim. Phillips 2002). Tämä voi osaltaan selittää saatujen sähköiskujen lukumäärän suurta eläinten välistä vaihtelua (vaihteluväli keskimäärin 1,1-14,3 sähköiskua / päivä koko harjoittelujakson ajalle laskettuna), sekä miksi sähköiskujen lukumäärä ei pudonnut pysyvästi nollaan harjoittelujakson aikana (katso kuva 2). Vasikat viettivät yöajan (klo 0-6) yleensä karsinassa, joten ne eivät käyneet tutkimassa harjoitteluaitaa koskaan yöllä. Yhdenkään vasikoista ei havaittu koskevan laitumen aitoihin laidunkauden aikana. Laitumella laidunnuskäyttäytymiseen liittyvä ympäristön tutkiminen on voinut vähentää vasikoiden kiinnostusta laitumen aitojen tutkimista kohtaan.

Harjoitteluaidan rakenteesta johtuen aidasta saatu sähköisku oli heikompi kuin normaaleissa laidunoloissa, koska sähkövirta ei kulkenut eläimen kehon läpi maahan, vaan kahden langan välillä eläimen turvan tai muun ruumiinosan koskettaessa molempia ylä- tai alalankoja (katso kuva 1B). Eläimen koskettaessa vain toista muovieristimellä yhdistetyistä langoista, se ei siis saanut sähköiskua. Jotkin vasikoista hankasivatkin niskaansa usein harjoitteluaidan ylimpiin lankoihin näennäisesti saamatta langoista sähköiskua. Suositeltavinta olisikin rakentaa harjoitteluaita siten, että eläimet saavat aidasta poikkeuksetta riittävän voimakkaan sähköiskun.

Vasikoiden saamien sähköiskujen lukumäärässä tapahtuneiden muutosten perusteella vasikat oppivat selvästi varomaan jaloittelutarhassa ollutta sähköpaimenaitaa jo yhden vuorokauden aikana, vaikka eläimet kävivätkin tutkimassa aitaa koko opetusjakson ajan. Oppimista näyttää tapahtuneen jopa opetusjakson ensimmäisen tunnin aikana. Yksi vuorokausikin siis lienee riittävä sähköpaimenaitaan opetusjakson pituudeksi, jos pidempää opetusta ei ole mahdollista järjestää. On kuitenkin syytä varmistaa, että jokainen eläin ehtii saada aidasta vähintään yhden sähköiskun ennen laitumelle siirtoa, vaikka onkin esitetty, että eläimet voivat oppia varomaan aitaa myös nähdessään toisen eläimen saavan siitä sähköiskun (McDonald ym. 1981).

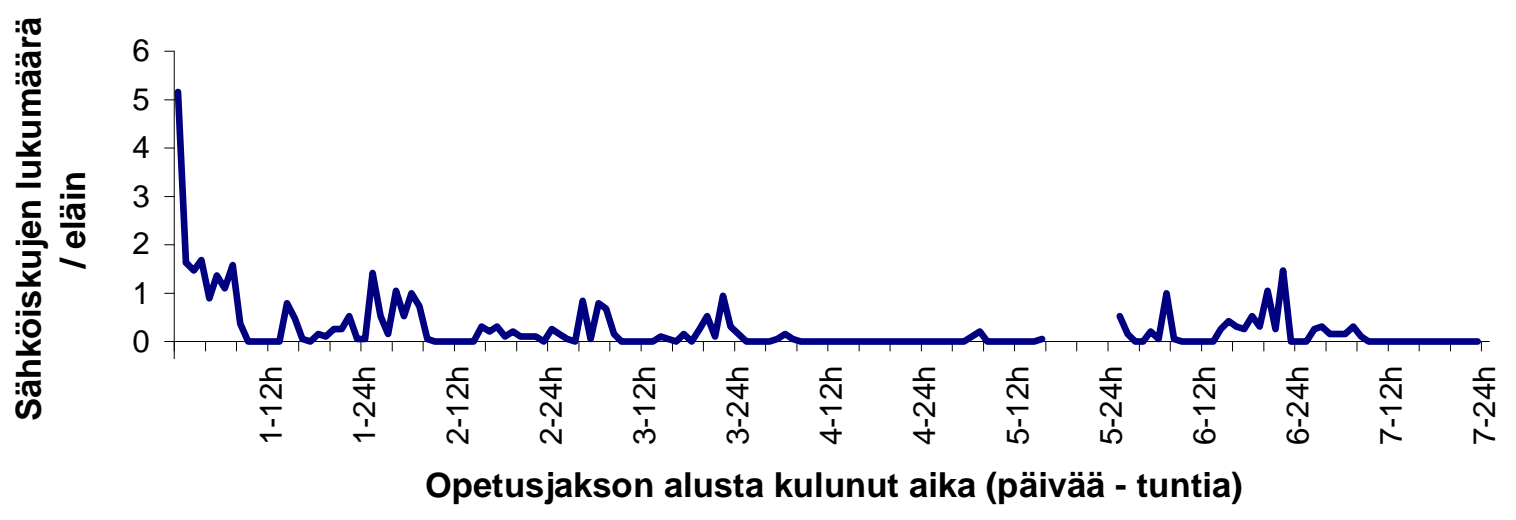

Kuva 2. Sähköiskujen jakautuminen vasikoiden sähköpaimenaitaan opettelujakson (yhteensä 7 vrk) ajalle. Viivassa oleva katkos kuvaa viidennen harjoitteluvuorokauden aikana tapahtunutta sähkökatkoa, jonka ajalta aineistoa ei ollut saatavilla. 


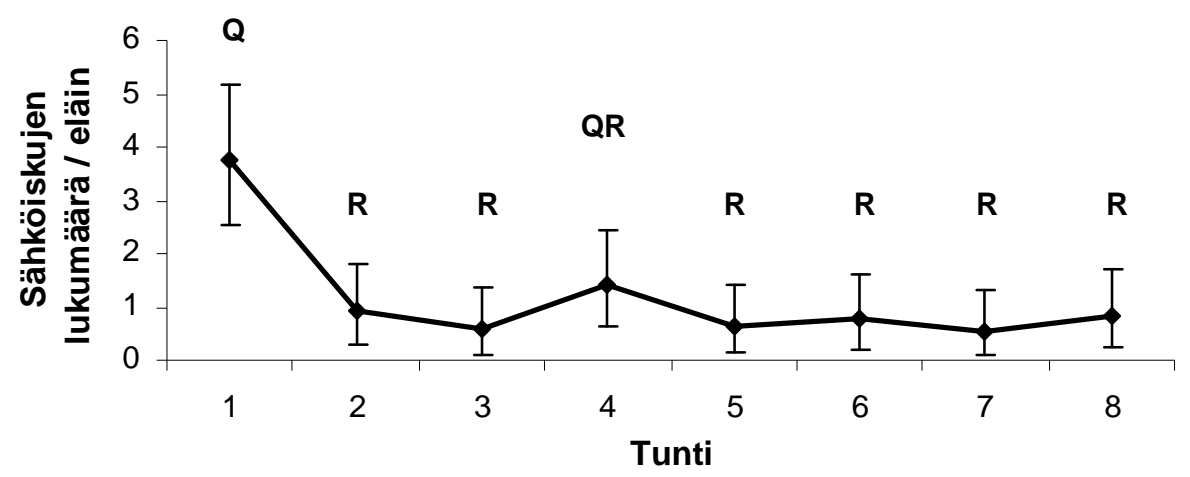

Kuva 3. Sähköiskujen lukumäärä eläintä kohden (takaisinmuunnettu marginaalikeskiarvo ja $95 \%$ luottamusväli) kahdeksan ensimmäisen sähköpaimenaitaan opettamistunnin aikana. Eri kirjaimet (QRS) tarkoittavat, että sähköiskujen määrässä on tuntien välillä tilastollisesti merkitsevä ( $\mathrm{P}<0,05$; lineaarinen sekamalli) ero.

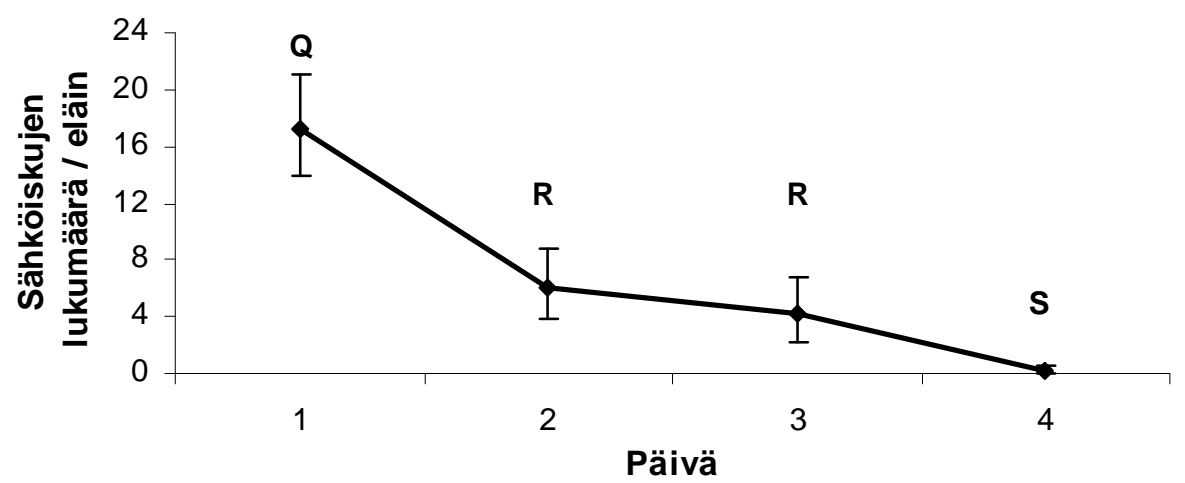

Kuva 4. Sähköiskujen lukumäärä eläintä kohden (takaisinmuunnettu marginaalikeskiarvo ja $95 \%$ luottamusväli) neljän ensimmäisen sähköpaimenaitaan opettamisvuorokauden aikana. Eri kirjaimet (QRS) tarkoittavat, että sähköiskujen määrässä on päivien välillä tilastollisesti merkitsevä $(\mathrm{P}<0,05$; lineaarinen sekamalli) ero.

Vasikoiden laitumelle laskusta kerättiin kuvailevaa tietoa suorilla havainnoilla noin tunnin ajan laitumelle laskun jälkeen. Eläimet kirmasivat laidunalueella, mikä on tyypillistä uudelle laitumelle pääseville naudoille (Hafez \& Bouissou 1975). Uuden ympäristön innostuttamat eläimet eivät välttämättä huomaa varoa etenkään sähköaitoja. Kaksi eläintä ensimmäisestä laitumelle lasketusta vasikkaryhmästä ryntäsikin pian laidunlohkoja erottavan väliaidan (kaksi rautalankaa) läpi. Aitaan lisättiin noin 10 cm leveä valkoinen aitanauha, eikä yksikään eläimistä enää juossut aitalankojen läpi, vaan eläimet joko pysähtyivät tai kääntyivät ennen aitaa. Jälkimmäisenä siirretyn ryhmän vasikat suljettiin siirrettävien puuaitojen avulla laitumella olleeseen suojakatokseen noin puoleksi tunniksi ennen varsinaista laitumelle laskemista, mikä saattoi jo ennalta rauhoittaa eläimiä. Tästä huolimatta vasikat kirmasivat molemmilla laitumilla noin puolen tunnin ajan ennen kuin ne rauhoittuivat syömään laitumelle tuotua rehua. Näyttäisi siltä, että hyvin näkyvistä aidoista voisi olla hyötyä etenkin laitumelle laskun yhteydessä, jolloin innostuneet eläimet voivat rikkoa aidat jopa "vahingossa". Laidunkauden aikana vasikat eivät kertaakaan karanneet omilta laitumiltaan, vaikka aidoista jopa katkaistiin sähkövirta laidunkauden loppupuolella.

\section{Sonnit}

Yhdeksää kokeessa olleista vasikoista laidunnettiin kahdessa ryhmässä vielä niiden yksivuotiskesänä. Sonnit siirrettiin ennen laitumelle laskemista pienempään aitaukseen, jonka sisäpuolelle oli rakennettu toimiva sähköpaimenaita. Jokainen sonni tutki sähköpaimenaitaa pian aitaukseen päästyään saaden siitä 1-2 sähköiskua. Tämän jälkeen eläimet olivat silminnähden haluttomia koskemaan aitaan uudelleen. McDonald ym. (1981) esittivät, että naudat varovat sähköpaimenaitoja pitkään saatuaan niistä sähköiskun. Sonnien käyttäytymisen perusteella voi olettaa, että eläimet muistivat edellisen kesän kokemuksensa ja osasivat varoa sähköpaimenaitaa vietettyään talven pihatossa. Jos eläimet ovat jo oppi- 
neet varomaan sähköpaimenaitoja, ne eivät välttämättä tarvitsekaan uutta muistutusta aitojen toiminnasta seuraavan kerran laitumelle päästessään.

Yksikään sonni ei karannut laitumelta, kun laitumen aitaan oli kytketty sähkövirta. Sähkökatkoksen aikana muutama eläin kuitenkin karkasi toisesta laidunryhmästä rikottuaan laitumen aidan aitauksen kulmasta. On mahdollista, että eläimet ovat rikkoneet aidan vahingossa, sillä sonnitkin näyttivät varovan aitaa, jossa kiersi sähkövirta. Siksi onkin epätodennäköistä, että eläimet karkaisivat laitumelta lyhyen sähkökatkon aikana muutoin kuin vahingossa. Etenkin sonneja laidunnettaessa lieneekin syytä varmistaa, että laitumen aidoissa kiertää jatkuvasti sähkövirta, sillä ei ole tutkittu, kuinka kauan eläimet yhden sähköiskun saatuaan välttävät sähköaitoja laidunoloissa.

\section{Suosituksia nautojen sähköpaimeneen opettamista ja sonnien laiduntamista varten}

Vasikoiden opettamista sähköaitoihin kannattaa harkita etenkin silloin, kun on tiedossa, että eläimiä tullaan pitämään laitumella jossakin niiden myöhemmässä elinvaiheessa. Koska sähköpaimenaidat itsessään ovat naudoille ennemmin psyykkinen kuin fyysinen este, eläinten opettaminen varomaan sähköpaimenaitoja ensimmäisen kerran on parasta toteuttaa vankemman aitauksen sisäpuolelle rakennetussa sähköpaimenaitauksessa. Näin sähköiskuista mahdollisesti hätääntyvät ja sähköpaimenaidan rikkovat eläimet eivät kuitenkaan pääse karkaamaan kauas ja aiheuttamaan lisävahinkoja itselleen tai ympäristölleen. Voi olla, että opettaminen olisi mahdollista toteuttaa jopa eläinten omassa karsinassa, jos siellä on riittävästi tilaa väistää aitoja. Oppimisen kannalta välttämätöntä on myös, että eläimellä on aikaa huomata saavansa aidasta sähköiskun (katso Moseby \& Read 2006). Tältäkin kannalta nautojen opettaminen varomaan sähköpaimenaitoja olisi helpointa toteuttaa eläinten ollessa vasikoita, jolloin suoraan aidoista läpi juokseminen on hankalampaa. Tulostemme perusteella voidaan vetää johtopäätös, että vasikkana opetetut eläimet osaavat varoa sähköpaimenaitoja vielä aikuisenakin sekä kohtalaisen pitkien taukojen (kuten sisäruokintakausi) jälkeen.

Toisin kuin aiemmin Suomessa tehdyissä sonnien laidunnuskokeissa (Nisula \& Hakkola 1979), kokeessamme sonnivasikoiden ja sonnien laiduntaminen onnistui sujuvasti. Esimerkiksi eläinten käsiteltävyys tai rauhattomuus eivät osoittautuneet ongelmiksi. Sonnien laiduntaminen kevytrakenteisissa sähköpaimenaidoissa on mahdollista, mutta ei varmasti sovi kaikille tiloille ja kaikkiin tilanteisiin. Etenkin lähellä olevat hiehot tai lehmät aiheuttavat sonneissa levottomuutta (katso esim. Hinch ym. 1982), joten laiduntamista ja laidunjärjestelyjä tuleekin harkita tapauskohtaisesti. Suosittelemme myös mm. hiehojen opettamista varomaan sähköpaimenaitoja ennen eläinten laskemista laitumelle turhien karkaamisten ehkäisemiseksi.

\section{Johtopäätökset}

Maitorotuiset sonnivasikat oppivat varomaan sähköpaimenaitaa nopeasti. Tulosten perusteella selkeää oppimista on tapahtunut jo ensimmäisen harjoitteluaitaukseen päästämistä seuranneen tunnin aikana. Sähköaitaan opetuksen jälkeen vasikoita voitiin vaivatta laiduntaa kevyillä sähköpaimenaidoilla aidatuilla laitumilla, eikä yksikään eläin karannut laidunkauden aikana. Myös vasikoina sähköpaimenaitaan opetettujen sonnien laidunnus onnistui ongelmitta. Suosittelemme laidunnettavien nautojen opettamista varomaan sähköpaimenaitaa jo eläinten ollessa vasikoita laitumelta karkaamisten vähentämiseksi.

\section{Kiitokset}

Tutkimusta on osittain rahoittanut Pohjois-Pohjanmaan Työvoima- ja elinkeinokeskus. Kiitämme MTT:n Ruukin toimipisteen henkilökuntaa eläinten hoidosta ja Vesa Kiviniemeä tilastotieteellisestä avusta.

\section{Kirjallisuus}

Barnard, C. 2004. Animal behaviour - Mechanism, development, function and evolution. Pearson Education Limited, Essex. $726 \mathrm{~s}$.

Box, G.E.P. \& Cox, D.R. 1964. An analysis of transformations. J. Royal Stat. Soc. B 26: 211-252.

Hafez, E.S.E. \& Bouissou, M.F. 1975. The behaviour of cattle. Teoksessa: Hafez, E.S.E. (toim.), The behaviour of domestic animals. 3. painos. Baillière Tindall, Lontoo. s. 203-245. 
Hakkola, H., Heikkilä, H., Helander, J., Holmström, M.-H., Joki-Tokola, E., Järvi, A., Nissinen, O., Pirkkalainen, T., Puurunen, T., Seppänen, H. \& Suvitie, M. 1998. Nurmenviljely. Maaseutukeskusten Liiton julkaisuja no 920. Maaseutukeskusten Liitto, Kokemäki. 107 s.

Haskell, M.J., Rennie, L.J., Bowell, V.A., Bell, M.J. \& Lawrence, A.B. 2006. Housing system, milk production, and zero-grazing effects on lameness and leg injury in dairy cows. J. Dairy Sci. 89: 4259-4266.

Hernandez-Mendo, O., von Keyserlingk, M.A.G., Veira, D.M. \& Weary, D.M. 2007. Effects of pasture on lameness in dairy cows. J. Dairy Sci. 90: 1209-1214.

Hinch, G.N., Thwaites, C.J. \& Lynch, J.J. 1982. A note on the grazing behaviour of young bulls and steers. Anim. Prod. 35: 289-291.

Jansson, S., Huuskonen, A. \& Honkavaara, M. 2007. Laidunnuksen vaikutus sonnien kasvuun sekä ruhon ja lihan laatuun. Teoksessa: Huuskonen, A. (toim.), Tuloksia lihanautojen laidunkokeista. Maa- ja elintarviketalous 95. Maa- ja elintarviketalouden tutkimuskeskus. s. 53-78.

Khalili, H. \& Sairanen A. 2000. Effect of concentrate type on rumen fermentation and milk production of cows at pasture. Anim. Feed Sci. Technol. 84: 199-212.

McDonald, C.L., Beilharz, R.G. \& McCutchan, J.C. 1981. Training cattle to control by electric fences. Appl. Anim. Ethol. 7: 113-121.

MMM 2002. Maa- ja metsätalousministeriö. Kotimaisen naudanlihantuotannon elvyttämistä selvittävän työryhmän loppuraportti. Työryhmämuistio MMM 2002:2. Helsinki. Saatavilla: http://www.mmm.fi/julkaisut/tyoryhmamuistiot/2002/tr2002_2.pdf

Moseby, K.E. \& Read, J.L. 2006. The efficacy of feral cat, fox and rabbit exclusion fence designs for threatened species protection. Biol. Conserv. 127: 429-437.

Nisula, H. \& Hakkola, H. 1979. Lihanautojen määrän vaikutus laitumen satoon. Kehittyvä Maatalous 42: 1222.

Phillips, C.J.C. 2002. Cattle behaviour and welfare. 2. painos. Blackwell Science, Oxford. 264 s.

Seppänen, H. 1978. Aitaaminen. Teoksessa: Paatela, J., Markkula, M., Sallasmaa, S., Siitonen, M. \& Kinanen, M. (toim.), Laidunopas. Maaseutukeskusten Liiton julkaisuja no 617. Maaseutukeskusten Liitto. s. 35-37. 